\title{
Frontiers
}

\section{in the Psychotherapy} of Trauma \& Dissociation

Environmental Safety: The Starting Point in the Treatment of Children with Dissociation Sandra Baita, Licensed Clinical Psychologist
The Official Clinical Journal of the International Society for the Study of Trauma and Dissociation 


\title{
Frontiers in the Psychotherapy of Trauma \& Dissociation
}

The Official Clinical Journal of the ISSTD

\section{EDITOR}

ANDREAS LADDIS, MD, Private Practice and Faculty, Boston University, School of Public Health, Boston, Massachusetts, USA

\author{
ASSOCIATE EDITOR \\ MARTIN J DORAHY, PhD, Professor, Department of Psychology, University of Canterbury, \\ Christchurch, New Zealand and The Cannan Institute, Brisbane, Australia
}

\section{EDITORIAL ASSISTANT}

COURTENAY CRUCIL, MA, RCC, Private Practice, Terrace, British Columbia, Canada

\begin{abstract}
Frontiers in the Psychotherapy of Trauma $\mathcal{E}$ Dissociation is published by the International Society for the Study of Trauma and Dissociation, Inc., 4201 Wilson Blvd Third Floor, Arlington, VA 22203
\end{abstract}

\section{Annual Subscription, Volume 4, 2020}

Online subscription is part of the membership dues of the International Society for the Study of Trauma and Dissociation. Visit https://www.isst-d.org/join-isstd/individualmember-benefits/.

Production and Advertising Office: ISSTD Headquarters, 4201 Wilson Blvd Third Floor, Arlington, VA 22203

Copyright $\odot 2020$ International Society for the Study of Trauma and Dissociation. All rights reserved. No part of this publication may be reproduced, stored, transmitted, or disseminated in any for or by any means without prior written permission from the International Society for the Study of Trauma and Dissociation. The publisher assumes no responsibility for any statements of fact or opinion expressed in the published papers. The appearance of advertising in this journal does not constitute an endorsement or approval by the publisher, the editor, the editorial board, or the board of directors of the International Society for the Study of Trauma and Dissociation of the quality or value of the product advertised or of the claims made of it by its manufacturer.

Subscriptions to this journal are acquired through membership in the International Society for the Study of Trauma and Dissociation only.

Visit https://www.isst-d.org/join-isstd/individual-memberhip-categories/.

Permissions. For further information, please write to info@isst-d.org.

\section{EDITORIAL BOARD}

ELIZABETH S BOWMAN, MD, Editor Emerita, Journal of Trauma \& Dissociation, Adjunct Professor of Neurology, Indiana University School of Medicine, Indianapolis, Indiana, USA

LAURA S. BROWN, PhD, Private Practice, Seattle, Washington, USA

RICHARD A CHEFETZ, MD, Private Practice, Faculty and Founding Member Institute of Contemporary Psychotherapy \& Psychoanalysis, Distinguished Visiting Lecturer: William Alanson White Institute of Psychiatry, Psychoanalysis \& Psychology, New York City, USA

CONSTANCE J DALENBERG, PhD, Trauma Research Institute, California School of Professional Psychology, San Diego, California, USA

J.K. JUDITH DANIELS, PhD, Faculty of Behavioural and Social Sciences, University of Groningen, The Netherlands

STEVEN N GOLD, PhD, Professor, Center for Psychological Studies, and Founding Director, Trauma Resolution \& Integration Program, Nova Southeastern University, Fort Lauderdale, Florida, USA ELIZABETH B HEGEMAN, PhD, Professor, Department of Anthropology, John Jay College of Criminal Justice, New York, New York, USA 
RICHARD P. KLUFT, MD, PhD Private Practice and Clinical Professor of Psychiatry, Temple University School of Medicine; Faculty Member, Philadelphia Center for Psychoanalysis,

Philadelphia, Pennsylvania, USA

CHRISTA KRÜGER, MD, Professor of Psychiatry, University of Pretoria, Pretoria, Gauteng, South Africa

KARLEN LYONS-RUTH, PhD, Professor of Psychology, Harvard Medical School, Cambridge, Massachusetts, USA

ALFONSO MARTÍNEZ-TABOAS, PhD, Professor, Albizu University, San Juan, Puerto Rico WARWICK MIDDLETON, MD, Adjunct Professor, Cannan Institute, Brisbane, Australia

ELLERT R. S. NIJENHUIS, PhD, Department of Psychiatry and Outpatient Department Mental Health Care Drenthe, Assen, The Netherlands

SANDRA PAULSEN, PhD, Bainbridge Institute for Integrative Psychology, Bainbridge Island, Washington, USA

VEDAT SAR, MD, Professor of Psychiatry, Koç University School of Medicine (KUSOM), Istanbul, Turkey

JOYANNA SILBERG, PhD, Trauma Disorders Program, Sheppard Pratt Health Systems, Baltimore, Maryland, USA

ELI SOMER, PhD, Professor, School of Social Work, University of Haifa, Israel

KATHY STEELE, MN, CS, Private Practice, Atlanta, Georgia, USA

ONNO VAN DER HART, PhD Emeritus Professor of Psychopathology of Chronic Traumatization, Department of Clinical and Health Psychology, Utrecht University, Utrecht, The Netherlands VICTOR WELZANT, PsyD, Sheppard Pratt Health Systems, Trauma Disorders Program

\section{REVIEWERS}

JOHN BRIERE, PhD, Associate Professor of Psychiatry and Psychology, University of Southern California Keck School of Medicine, Los Angeles, California, USA

SHELDON IZKOWITZ, PhD, Clinical Associate Professor of Psychology and Clinical Consultant, Postdoctoral Program, New York University, New York City, USA and Teaching Faculty \& Supervisor of Psychotherapy and Psychoanalysis, National Institute for Psychotherapies, New York City, USA

MARY-ANNE KATE, PhD Researcher at University of New England, Australia; University of New England, New South Wales, Australia

ULRICH F. LANIUS, PhD, Private Practice, West Vancouver, British Columbia, Canada

\section{SUPPORTERS}

ISSTD thanks its generous supporters whose contributions have made this publication possible:

Andreas Laddis, MD, USA

\section{The \\ Cannan \\ Institute}

Cannan Institute, Australia

Warwick Middleton, MD, Australia

Dana Ross, MD, Canada

Martin J. Dorahy, PhD, New Zealand

Kate McMaugh, Australia

Sara Y. Krakauer, USA

Paula Eagle, MD, USA 


\title{
ARTICLE
}

\section{ENVIRONMENTAL SAFETY: THE STARTING POINT IN THE TREATMENT OF CHILDREN WITH DISSOCIATION}

\author{
SANDRA BAITA, Licensed Clinical Psychologist \\ Private practice, Buenos Aires, Argentina
}

\begin{abstract}
Lack of safety in the world surrounding the child is a major roadblock for the treatment of complex post-traumatic sequelae and dissociative manifestations. Unfortunately, this is a common situation in cases involving a parent being abusive towards the child-either sexually or physicallywhen the alleged offending parent is allowed and even encouraged to have contact with the child. Through the case of Ann, readers will follow the many pitfalls faced in the treatment of the traumatic consequences of the sexual abuse she suffered, until environmental safety was achieved. The role of the Justice system will also be discussed.
\end{abstract}

KEYWORDS safety; neuroception; environment; sexual abuse; attachment; dissociation

\section{INTRODUCTION}

A stage-oriented model of therapy for complex trauma and dissociation in children requires as a first step that the child is protected from the contact with the perpetrating adult(s) (Struik, 2014; Waters, 2016). According to Stien and Kendall (2004, p. 141), "maintaining a predictable daily structure both reinforces a child's sense of control and counteracts the tendency

Acknowledgement: The author would like to acknowledge the constant support of the leaders in the field of childhood dissociation Renée Marks, Joyanna Silberg and Fran Waters, and the late Sandra Wieland for her invitation to reflect together about our practice.

Correspondence: 11 de Septiembre 4085, 7/D, (1429), City of Buenos Aires, Argentina; Phone: (0054) 9113409 9344. E-mail: sbaita68@gmail.com. 
to regress and become fully immersed in the traumatic past." The authors cite a study of about 150 foster children in San Diego, in which children who were reunified with their parents were much more likely to exhibit mental health problems than those who did not (Stien \& Kendall, op.cit). In Argentina the ultimate protection of children from further abuse by their biological parents relies on the family judicial system, following the intervention of the local Child Protective Services. However, for many family courts, the idea of keeping a child separated from the alleged offender is not easy. In many cases, children are reunified with their parents, even if there is no evidence to support that the potential for further harm has diminished or disappeared. The reunification processes can go from therapeutic processes in which the child and the alleged offender participate together without any discussion of the reasons that led to the previous separation; supervised visits (either by a social worker or by the child's relatives) and unsupervised visits. Courts follow no protocols nor specific criteria to decide which type of reunification will be ordered. Reunification may happen even if the criminal prosecution has not concluded.

The experience of safety derives from an attuned relationship between the child and caregiver. Attuned communication, repair of disruptions within this communication, appropriate soothing of tension, and proper regulation of affective states by caregivers set the stage for the development of the experience of safety within the most important relationship a newborn has. When caregivers can't fulfill these tasks, children develop insecure styles of attachment and their experience of safety within a relationship is jeopardized. When the relationship with a caregiver is abusive and unpredictable, the whole environment of the child becomes unsafe, not just the relationship; some children can experience more safety staying on the streets than within their own homes due to the intense and chronic violence they have suffered (de Singlau, 2015).

Porges (2017, p. 44) with regard to the Polyvagal theory he has developed-instrumental in our understanding of how our nervous system experiences safety, danger and life threat—-states that "by moving the defining features of "safety" from a structural model of the environment with fences, metal detectors, and surveillance monitoring to a visceral sensitivity model evaluating shifts in the neural regulation of autonomic state, the theory challenges our societal values regarding how people are treated. The theory forces us to question whether our society provides sufficient and appropriate opportunities to experience safe environments and trusting relationships." Such a quote is remarkably adequate to the study of the clinical case of Ann whose safety experience was attacked first by a primary relationship (her father) and later by the external system that was supposed to protect her from further damage (the judicial system).

The goal of this paper is to review the several interventions and the time spent to treat Ann within a context of environmental lack of safety, and the fast progress conquered when external safety was finally achieved. 


\section{A POWERFUL MONSTER}

Four year old Ann and her therapist are sitting under a table in a corner of her therapistsâĂ $\ddot{Y}$ office. This is the place Ann chose to spend her therapy sessions from the very beginning.

With a quiet voice, eyes down, the little girl tells her therapist: "Don't bother Sandra, the monster will break in, no matter you've locked the door." The passivity in her tone is striking.

Her drawings are filled with concerns about safety and protection for a baby and her mom: lasers, fences, thunderbolts, caves. Her play is full of dangerous situations where "the monster" is pushing to break into the places where Ann is: her home, the school playground, her therapistsâĂ $\ddot{Y}$ office. More "quiet" games revolve around mom taking her baby to the doctor, and the doctor removing thorns from the baby's vagina. Ann keeps saying: The baby is hurt but is unable to explain how she got these thorns inside of her vagina.

Ann concerns about not feeling safe inside the therapy setting are shocking: she can't take her attention away from her surroundings. Being in a locked office in the seventh floor of a building with surveillance at the entry is not enough. The urban landscape she can see outside the closed windows terrifies her as well. Sometimes being under the table is not enough, and she asks her therapist to cover all the places that expose her to the environment.

Is this child's experience related to her past trauma? Yes, but only partially.

When Ann was around three years and a half, she spontaneously told her mom about a sexual game daddy used to play with her. Mom was in shock. She had divorced Ann's dad when she was 18 months, but they had been able to keep a good relationship. After some consultations, mom reported the sexual abuse allegations to the judicial system, only to find out that the second part of this nightmare was about to begin. Ann was assessed three times by three different professionals; the assessments included one made by a forensic psychologist who acknowledged she did not have experience with children, and another one in the presence of her father, which is absolutely not recommended for the investigation of sexual abuse allegations (Coulborn Faller, 2007). The general conclusion of all these assessments was that the abuse didn't happen, that Ann had a loving relationship with her dad, and that mom was a confrontational, highly dysregulated woman. The accusation was dismissed, and the case was closed.

The family court decided then there was no impediment for Ann to see her dad again after a period of interrupting the contact between them. However, Ann kept telling mom about the sexual games she played with daddy. Mom decided then that —at her own risk—she would disobey the 
court order: she didn't want Ann to see her father, because she believed her daughter was telling the truth and was afraid he would harm her again.

By the time I started seeing Ann, the father was fighting to regain contact with his daughter. He did this both in court with his lawyers and outside of it by himself: he would break into mom's office yelling at her that he wanted his daughter back, he would appear unexpectedly at her home claiming to see Ann, he would ask his relatives to put pressure on Ann's mom on the streets, at her door, wherever they could find her.

Despite the constant surveillance of the place and the hypervigilant state, Ann was able to make with me a very clear statement of the sexual abuse she had suffered at the hands of her dad which I reported both to the criminal court and the family court; whereas the first reopened the case, the latter was firm about the decision that the little girl should see her father, even if she claimed he had abused her. The family court judge went even further in deciding that-because of mom's disobedience-Ann should spend two weekends a month at her dad's place, where she would also spend nights with him.

What monster was Ann talking about then? Was it a monster living only inside of her imagination?

\section{DESPERATELY SEEKING FOR SAFETY}

In cases of child abuse, environmental safety is the ground zero in the treatment of children who suffered interpersonal violence. Environmental safety is concrete, real, and external to the individual. It's related to the community where we live, but it is also related to the life conditions within our own home. During childhood, environmental safety must be provided and guaranteed by adults, especially by the child's caretakers (Baita, 2019).

Children are born capable to neurocept safety (Porges, 2011) but neuroception of safety doesn't occur automatically. When children like Ann relate to parents who harm them, they start experiencing an odd alternation between a caregiver who sometimes doesn't harm (and then provides an experience of safety within the relationship) and the same caregiver that some other times does harm the child (and then provides an experience of danger, pain and fear within the same relationship with the same person). When this alternation occurs along the time, which is the case of any experience of child abuse, the child's brain will expect danger rather than safety within this relationship and will eventually scatter the same expectation to any relationship with an adult, including a therapist.

In order to decide whether a child's environment is safe in cases involving the abuse by a parent, we have to answer three fundamental questions (Baita, 2019, op.cit):

1) Is the child still in contact with the person who harmed her? 
2) If the child is not in contact with the person who harmed her, are there any concerns that this will happen in the near future without knowing whether the conditions that lead to the harm have changed or not?

3) Is the non-offending caretaker facing the same or a similar situation the child is exposed to?

Ann was exposed to several factors that put at risk her environmental safety:

a) whereas one of the caretakers was directly involved in harming Ann (the father), the other one (the mother) was involved in protecting her by fighting against a system that imposed actions contrary to Ann's safety. Mom was emotionally overwhelmed because she felt completely alone and resourceless in the task of providing safety to her child; she was in a permanent state of alert expecting her ex - husband would break in and take Ann with him, so her ability to soothe Ann's tension and provide her a sense of security was at stake;

b) if a child cannot be properly protected by her caretakers (like in the case where the child is abused by her primary caregivers) the external system composed by the child protective services and the family justice system should be able to take the lead in protecting her from any harm, which in Ann's case did not happen.

Was a safe environmental therapeutic setting enough to make this little girl feel safe? The answer was easy: no.

As an EMDR clinician I was taught some basic concepts that very soon proved to be of little use when working with children like Ann. During Phase 2 of the treatment standard protocol the clinician is encouraged to develop and install with the client resources that could help her change affective states while navigating the reprocessing of traumatic memories. The client is also taught to make a STOP signal to warn the clinician that the exposure to the traumatic memory is being too painful to tolerate. With this signal both therapist and client stop the reprocessing and put a break on the flooding of traumatic material by using any of these resources aimed to help the client go back to her window of tolerance. Then a decision is made about whether to resume the reprocessing during that session or not (Shapiro, 2001).

One of these resources is called the Safe/Calm Place, a visualization of a real or imagined place where the client can feel peaceful, calm, safe, and in control. When I work with children, I like to make this place more vivid, like creating the place (a tent, for instance) in my office, or making a drawing that will be exposed during the reprocessing so the child can easily access it when needed. Being cuddled by an attuned and regulated parent can also be used as a resource.

In my work with Ann it was clear from the very beginning that no safe place could be invented nor imagined if she couldn't find safety in her real world. Not even the creation of a "safety capsule" within my office 
(sitting on the floor, under the table and covered by my coat) was enough for her: "Sandra, the phone is ringing, I think it's the monster calling you," "Sandra, don't bother to tell the monster he cannot get in here, he is far more powerful than you," "Sandra, do you think the monster can see what am I doing even if I'm hidden? I think he can." Inviting her mom was not useful either: Ann refused to receive bilateral stimulation of any kind, and her constant uneasiness made many sessions with mom present quite difficult to organize around a specific issue. Of course, if mom didn't feel safe either in her efforts to protect her child, how could she provide a sense of security to Ann even in my office? Session after session, I repeated to myself the same question: What was the scope of my intervention in this situation?

\section{LOOKING FOR THE HEAVEN OF SAFETY IN THE HELL OF DAILY LIFE}

An adult client told me once, referring to the inescapable situations she lived when she was a child within a violent and chaotic environment: "When my mother came to my bed, seeking shelter from my dad's violent behavior, I had this double awkward feeling: on one side I could feel her warmth that calmed me down, and at the same time I could feel her body trembling that made my own body shake with fear as well. It was like spending the night in Heaven and Hell at the same time."

This was certainly Ann's experience as well. Her mom was emotionally overwhelmed not only by the news about the abuse her little daughter had disclosed to her, but especially for the lack of help she was receiving form the external systems that were supposed to back her up in protecting little Ann. As a last desperate measure, Ann's mother decided to send her daughter to live with her maternal grandmother in a town an hour and a half away from her home. Since mom had to work in the city to sustain her daughters needs and to keep up with the legal situation, she would spend weekdays in the city and visit Ann at her mother's place in the weekends. She told her daughter this was to protect her, and even if Ann had the most affectionate relationship with Grannie, every time she saw her mom leaving her until the next weekend, she would cry desperately asking mom to take her back to the old house.

The hypervigilant state during sessions changed then to a hypoactivated state. Most of the time, Ann arrived into my office sleepy, unresponsive, and claiming to be extremely tired. She wouldn't engage in any activity, nor drawing, or playing. Sometimes she would just lie down on several cushions claiming to need a nap. Her sleepy state was so contagious I found myself asking whether my tiredness was entirely mine, or hers. According to Silberg (2013, p. 132-133) not being aware of what happens around you (or inside of you) can be helpful "when you are helpless to 
escape the inescapable. While the child feels that at that moment not knowing is key to psychological survival, as a therapist you know survival and thriving depends on awareness and the choice of what to avoid or what to approach."

After trying to keep her awake, I found I could only follow the flux of her minimal activity, feeling that putting any pressure to go further with her would be inadmissible for her little nervous system. Would she need to take a nap? She did. Would she need to draw silently? I would draw silently with her.

Progressively Ann's sleepiness ceased; during the next sessions she was clearly awake, but yet unresponsive. However, this unresponsiveness was of a different kind: Ann would sit in a corner turning away from me, playing solitary games, and wouldn't answer any of my questions. I felt like I was quite invisible.

"It looks like the Ann that came to see me today has decided she does not want to talk to me, or look at me, or play with me... I wonder whether this is the same Ann that was so tired she needed to take a nap..." I reflected to her one day.

“No. It's a different Ann. It's an 'Ann No.' "-she answered back.

More about the internal world of Ann was about to unfold.

\section{DISSOCIATION IS A SURVIVAL STRATEGY}

Theoretical constructs are born to help us, clinicians, to understand our clients' experiences. But no matter how many theories we elaborate, for them, dissociation is, indeed, a survival strategy. How would Ann survive the daily ordeal of having her dad harassing mom to fulfill the court order and let their little daughter go with him, even if he was accused of having abused her? How would she deal with her emotionally overwhelmed mom was facing in this situation? How would Ann reconcile the fact that in order to be more protected by mom, she had to be away from her?

One day Ann came to my office stating that she had two different memories inside of her mind:

"I have a memory that says my dad touched me, and I have another one that says he did not."

"And which memory would you like to talk about today?"- I asked her.

"None of them."

In order to avoid the painful memories of abuse and the conflict between knowing and not knowing, Ann No came to help Ann deal with all this stuff.

Sessions passed trying to know more about Ann No and the internal world of Ann. Eventually I was able to understand that Ann No had a very negative self-concept that made this part believe I didn't want to engage 
with her. The work was then directed towards creating a bond between me and this part.

Ann then disclosed two more parts: Ann Yes, and Little Ann Yes. Ann Yes was older, calm, wise, and represented the part of Ann that struggled to adapt to her new school environment (as opposed to Ann No, responsible for doing things Ann would get grounded for or causing her pals at school to back her off). Little Ann Yes was younger than Ann and was, probably, the part holding all the good experiences of happiness and playfulness Ann missed from her life before disclosing the abuse of her father.

We spent several months working towards communication and cooperation between the Ann Yes system of parts and Ann No. Strategies were tried and failed one after another. Ann complained about the evilness of Ann No, the disobedience of this part, the hostility directed towards the other parts, herself, and the external world.

What caused this "evilness"? Was this part sad, angry, anxious, and ashamed? For each of these answers Ann would repeatedly answer "I don't know, the only thing I know is that she is mean."

Eventually Ann recognized the need for protection each of her parts had by creating a little cave for each of them with a secret password at the entrance to lock them in when they felt in danger. The more I acknowledged and validated each of these parts, the more Ann was engaged in encouraging them to relate to each other. Finally, she decided we could put the three of them inside one cave. Following the spirit of The Dissociative Table Technique (Fraser, 2003) we created a dissociative cave, with a bedroom for each of the parts and a living room where they would agree to stay together without rejecting nor attacking each other, but rather listening to each other. We created a finger puppet representing each of the parts and Ann spent several sessions practicing an avoidance-approach dance between her and her parts and between the parts themselves.

\section{FINALLY, SAFETY HAS ARRIVED}

Almost two years had passed since I began treating Ann, when her father went to trial for the accusation of sexual abuse against his daughter. The criminal court found him guilty of the charges and since dad didn't go to prison immediately the sentence forced the family court to suspend the previous decision of allowing contacts between him and his daughter.

Mom communicated the facts to Ann in a joint session. Ann was sitting on her mom's lap, quiet and silent. After listening to mom, Ann made a draw and said: "This is my brain. It's burned. I have nothing inside of it. Nor bad things or good things. I think I must refill it."

I felt Ann was so tired of the journey she had done since she revealed the sexual abuse by dad, she barely had energy to continue exploring what 
was inside of her. I could feel her sense of not knowing what to do, where to go and how to get there. Or was this my own feeling? I decided to stay with this feeling, open my door and invite it to play (Rubenstein, 2013).

A couple of sessions later, Ann was eager to share with me more facts about the Anns living inside of her. Here is what she shared with me:

"Ann No is angry. She is mad at her dad for all the things he did to her. But she is also mad at the other Anns because she doesn't want to share their mom with them."

"Why does she have to share their mom? What happened to Ann No's mom?"

"She left her because Ann No was mean. She left her when Ann No was three years old and never returned. So, Ann No came to live with the other Anns but she wanted a mom for herself, because she missed her so much."

"So, you say that Ann No's mom abandoned her because she was mean. What did she do?"

"This I don't know."

Was the "misbehavior" of Ann No to talk about the sexual abuse of her dad (the abuse came to light at three and a half years old, around the age Ann says the mom abandoned Ann No)?

Was the commitment of Ann's mom to fight an unfair and unsafe court order, the burden of this fight and the late sending of Ann to her Grandma's home, what the Ann No part felt as her mom abandonment?

Both things seemed to be very likely. So, my next move would be to process the traumatic memories not only of the abuse, but also of the feeling of loneliness this little girl had had when her mom detached from her to protect her. My clinical decision was to start with the memory linked to the feeling of abandonment by her protective attachment figure.

Using the narrative model developed by Joan Lovett to process traumatic memories using EMDR (Lovett, 2015) I asked mom to write a story of what happened from before she knew about the abuse until the present moment -including the knowledge about dad's abuse, the court involvement, the flying to Grannie's home and the trial, adding information about the loving relationship she and Ann had always had.

I first presented the idea to Ann in order to have both her and her internal word's permission to work through it:

"I think we can help Ann No with her feeling of being abandoned by her mom..."

"How?"

"It might be good to have mom here with us telling the story of how much she cared about you and everything inside of you..."

"I like stories. .."

"Would you like to check inside whether the Anns agree with this?" 
Ann put the finger puppets on her fingers and brought each of them to her ear.

"They agree."

Our next step was to decide what part needed to know the story and what would the other parts do while mom was telling it:

"We can set up the place for them to listen to mom telling the story. Which one do you think is the one that needs the most mom's story?"

"Ann No... she is the one who lost her mom... she will like to have my mom telling her a story."

"Ok, and what about the other Anns?"

"We can place them in the cave's living room, so they can listen to the story too. I will hold Ann No with me."

Before the joint session I decided to have a session with mom alone. I wanted to check her affective state while reading the story: we needed mom to stay regulated during this task in order to prevent Ann from being overwhelmed by her mother's unprocessed experiences. Even if mom had her own therapy, since her therapist was not an EMDR clinician, she agreed to desensitize the most disturbing parts of the story while reading it to me.

At the joint session mom was calm and supportive. Ann felt confident in showing her the stage where Ann No would listen to her story.

"Great job Ann! You said you wanted to hold Ann No while listening to mom's story."

Ann put the finger puppet representing Ann No on her finger.

"And where would you and Ann No like to stay while mom is telling the story? Once you are both ready just let me know..."

Ann sat on mom's laps.

"You can start mom..."

The decision was to have mom telling the story. Her voice was far more familiar than mine; it was her voice that was carrying the attachment information the Ann No part needed at that point. So my job was to pay attention to the entire process and do the bilateral stimulation, using the buzzers we have worked with before, which Ann liked very much because she could control the intensity of the buzzing.

Ann listened very attentive to the story while receiving the bilateral stimulation. She wanted the story to be read twice, which mom did. By the end of the second time mom read the story, she put the Ann No finger puppet on mom's finger.

"Does Ann No feel this is her mom too?" I've asked.

Ann nodded.

"And how does she feel now?"

Ann smiled. now?"

"Would you like to draw how you and all the Anns inside of you feel

Ann drew a girl with a big smile and a happy face, Jaraising her arms to the sky. 


\section{CONCLUSION}

By the time Ann was 6 years old, we were able to heal her experience of abandonment by her mom. But Ann No didn't integrate. This part was still holding the memories of the abuse by her father. However, Ann said she didn't want to go into this and that she needed a break from therapy. Many of the sexually abused children I have treated during all the prosecution of their parents, have lived these periods of time suspended over a court decision around their future: will I have to see my dad again? The case of Ann is not an exception in the treatment that family courts give to intrafamilial sexual abuse. The less safe the child feels during this period, the less work can be done to adequately process the memories of abuse. Sometimes psychotherapy alone is not enough.

I saw Ann again at 8 and 12 years old and we were able to process more memories about the abuse only after long-lasting and stable environmental safety was achieved, and she had no more news about her dad. At 12 she asked me to see all the things she did when she was a little child.

"I feel like I was a crazy girl back then..." she said smiling.

"I think your brain did a great job trying to protect you from all the awful things you were going through..."

"I recall you told me that we were working to lock these memories inside a little house, and that I would have the key to decide whether to open it or not, rather than being chased by them..."

"Do you think we made it?"

"I think so."

And so, Ann No, Ann Yes and Little Ann Yes became, finally, another memory of Ann's childhood experience.

A final reflection comes to my mind: should child trauma therapists be only clinicians, or should we advocate for the protection of the children we treat? And if the latter is true, to what extent should we advocate for our little clients' protection and well-being?

Silberg (2013, p. 141) provides a concrete and powerful answer to these questions: "To the extent that you have power to influence court decisions, school placement decisions or parenting practices, you should try to do so. Children really are powerless, and traumatized children are doubly so."

\section{REFERENCES}

Baita, S. (2019). La seguridad en los niños expuestos a trauma interpersonal temprano: desafíos para el modelo EMDR. Primera Cumbre Virtual Iberoamericana de la Terapia EMDR. AGATE Institute.

Coulborn Faller, K. (2007). Interviewing children about sexual abuse: Controversies and best practices. New York, NY: Oxford University Press. 
De Singlau, F. (2015). ¿Niños, niñas y adolescentes "de la calle", "en la calle" o "en situación de calle"? Una aproximación conceptual. Cuadernos Universitarios. Publicaciones Académicas de la Universidad Católica de Salta, 8, 51-62.

Fraser, G. (2003). Fraser's "Dissociative Table Technique" revisited, revised: A strategy for working with ego states in dissociative disorders and ego-states and ego-state therapy. Journal of Trauma and Dissociation. 4(4), 5-28.

Lovett, J. (2015). Trauma attachment tangle. Modifying EMDR to help children resolve trauma and develop loving relationships. New York, NY: Routledge.

Porges. S. W. (2011). The polyvagal theory. Neurophysiological foundations of emotions, attachment, communication, self-regulation. New York, NY: W. W. Norton \& Co.

Porges, S. W. (2017). The pocket guide to the polyvagal theory. The transformative power of feeling safe. New York, NY: W.W. Norton \& Co.

Rubenstein, L. (2013). Visiting feelings. Washington, DC: Magination Press/American Psychological Association.

Shapiro, F. (2001). Eye movement desensitization and reprocessing: Basic principles, protocols and procedures. New York, NY: The Guilford Press.

Silberg, J. L. (2013). The child survivor: Healing developmental trauma and dissociation. New York, NY: Routledge.

Stien, Ph. T. \& Kendall, J. (2004). Psychological trauma and the developing brain: Neurologically based interventions for troubled children. New York, NY: The Haworth Maltreatment and Trauma Press.

Struik, A. (2014). Treating Chronically Traumatized Children: Don't let sleeping dogs lie! London, UK: Routledge.

Waters, F. S. (2016). Healing the fractured child: Diagnosis and treatment of youth with dissociation. New York, NY: Springer Publishing Company. 